\title{
Rota Virus Vaccine Induced Immune Thrombocytopenia
}

\section{Sanjeev Kumar Sharma*, Vipin Khandelwal, Divya Doval, Meet Kumar, Ankur Jain and Dharma Choudhary}

Department of hemato-oncology and bone marrow transplantation, BLK Superspeciality Hospital, New Delhi, India

*Corresponding Author: Sharma SK, Department of Hemato-oncology and Bone Marrow Transplantation, BLK Superspeciality Hospital, New Delhi, India, Tel: 011 3040 3040; E-mail: sksanjeev13@yahoo.com

Received date: September 24, 2018; Accepted date: September 28, 2018; Published date: September 29, 2018

Copyright: () 2018 Sharma SK, et al. This is an open-access article distributed under the terms of the Creative Commons Attribution License, which permits unrestricted use, distribution, and reproduction in any medium, provided the original author and source are credited.

\begin{abstract}
Rota virus is a common cause of diarrhea in infants. Rarely, it has been reported to cause immune thrombocytopenia (ITP). Oral rota virus vaccine has been used to reduce the incidence of rota virus induced diarrhea, however, the vaccine can cause diarrhea. We report here a case of rota virus vaccine induced acute ITP which responded to intravenous immunoglobulins.
\end{abstract}

Keywords: Pathophysiology; Thrombocytopenia; Rota virus vaccine

\section{Introduction}

Various vaccines have been reported to cause ITP including mumps-measles-rubella vaccine (MMR) [1,2], diphtheria-pertussistetanus vaccine (DPT) [3], rabies [4] and oral polio vaccine [5]. The pathophysiology involves immune mediated mimicry and destruction of platelets by anti-platelet antibodies [6]. We report hare a case of rota virus vaccine induced acute ITP which responded to intravenous immunoglobulins.

\section{Case Description}

A 4-month-old female child was admitted with loose stools for 3 days and petechial spots over her limbs for 1 day. There was no fever or bleeding from other sites. On evaluation it was revealed that the child had received rota virus vaccine 10 days back. The child was otherwise active with no lymphadenopathy or organomegaly and no failure to thrive. She did not have any stigmata of inherited marrow failure syndrome. Her hemogram showed hemoglobin $11.8 \mathrm{~g} / \mathrm{dl}$, total leucocyte count $6.4 \times 10^{9} / 1$ and platelet count $12 \times 10^{9} / 1$ with normal differential counts for age. Her viral workup for human immunodeficiency virus, hepatitis $\mathrm{B}$ virus, hepatitis $\mathrm{C}$ virus and TORCH (toxoplasmosis, rubella cytomegalovirus and herpes simplex) was negative. There was no history of thrombocytopenia in mother during pregnancy and the child was delivered at full term by lower segment cesarean section. There was no family history of thrombocytopenia or any hematological disorder. Considering the clinical diagnosis of immune thrombocytopenia she was treated with intravenous immunoglobulins (IVIG $1 \mathrm{~g} / \mathrm{kg} /$ day, single dose) to which she responded completely in 2 days and was in remission on followup at 1 month. There was no further bleeding from any site.

\section{Discussion}

ITP is an autoimmune condition resulting in increased platelet destruction. Immune thrombocytopenic purpura in infants has been reported following immunization and usually has good response to treatment. The most common vaccine implicated in causation of ITP is MMR vaccine $[1,2]$.
Rotavirus is a double-stranded RNA virus belonging to the reoviridae family. Human rotavirus is the major etiological agent of diarrhea in infants and children throughout the world [8]. ITP has rarely been reported to be associated with either rotavirus infection or vaccine $[7,8]$. A study by Ai et al. showed that ITP children with rotavirus infection were significantly younger and presented a significantly higher frequency of bleeding against ITP children without rotavirus infection [4]. Thrombocytopenia following vaccination depends on the development of autoantibodies that cross-react with the naturally present antigenic targets on platelets [6]. Our case highlights that rota virus vaccine can be causative agents of vaccine associated ITP and should be considered whenever a child presents with thrombocytopenia following any recent vaccination. It responds well to treatment and has a good prognosis as shown by other studies with vaccine induced ITP $[6,8]$. This is a rare manifestation of rota virus vaccination as about 26 babies were vaccinated during that period but only one baby developed ITP.

\section{Conclusion}

Rota virus vaccine can be a causative factor of vaccine induced ITP and shows good response to the treatment. A high index of suspicion on the causative role of recent vaccination should be considered in the evaluation of child with ITP.

\section{References}

1. Millera E, Waight $P$ (2001) Idiopathic thrombocytopenic purpura and MMR vaccine. Arch Dis Child 84: 227-222.

2. Black C, Kaye JA, Jick H (2003) MMR vaccine and idiopathic thrombocytopaenic purpura. Br J Clin Pharmacol 55: 107-111.

3. Arya LS, Ghai OP, Saraya AK (1993) Thrombocytopenic purpura following DPT vaccination. Pediatr Hematol Oncol 10:381-383.

4. Sharma SK, Seth T, Agrawal N, Mahapatra M, Mishra P (2012) Immune thrombocytopenic purpura following anti-rabies vaccines. Platelets 23: $317-318$.

5. Jin CQ, Dong HX, Sun ZX, Zhou J, Dou C, et al. (2013) Acute immune thrombocytopenic purpura as adverse reaction to oral polio vaccine. Hum Vaccin Immunother 9: 1739-1740.

6. Blanchette V, Bolton-Maggs P (2008) Childhood immune thrombocytopenic purpura: diagnosis and management. Pediatr Clin North Am 55: 393-420. 
Citation: Sharma SK, Khandelwal V, Doval D, Kumar M, Jain A, et al. (2018) Rota Virus Vaccine Induced Immune Thrombocytopenia . J Blood Lymph 8: 227. doi:10.4172/2165-7831.1000.227

Page 2 of 2

7. Siddiqui AH, Chitlur MB (2010) Immune thrombocytopenic purpura in a 5-month-old female with rotavirus infection. Pediatr Blood Cancer 54:633.
8. Ai Q, Yin J, Chin S, Qiao L, Luo N (2016) Rotavirus-associated immune thrombocytopenic purpura in children: A retrospective study. Exp Ther Med 12: 2187-2190. 